\title{
Effect of Extracts from Citric Biomass, Rusted Coffee Leaves and Coffee Berry Husks on Phoma costarricencis of Coffee Plants
}

\author{
Beatriz M. Barguil², Mário Lúcio V. Resende, Renata S. Resende, \\ J. Evando A. Beserra Júnior \& Sônia M. L. Salgado \\ Depto de Fitopatologia, Universidade Federal de Lavras, Cx. Postal 37, Lavras, MG, Brazil, CEP 37200-000, \\ e-mail: mlucio@ufla.br
}

(Aceito para publicação em 12/07/2005)

Corresponding author: Mário Lúcio V. Resende

BARGUIL, B.M., RESENDE, M.L.V., RESENDE, R.S., BESERRA JÚNIOR, J.E.A. \& SALGADO, S.M.L. Effect of extracts from citric biomass, rusted coffee leaves and coffee berry husks on Phoma costarricencis of coffee plants. Fitopatologia Brasileira 30:535-537. 2005.

\begin{abstract}
Phoma leaf spot, caused by Phoma costarricensis poses a serious threat to coffee (Coffea arabica) production, especially in the highlands of the state of Minas Gerais, Brazil. Extracts of citric biomass, coffee berry husks and coffee leaves severely affected by rust caused by Hemileia vastatrix, were evaluated against $P$. costarricensis. In an in vitro assay, aqueous extracts of rusted leaves and berry husks plus the commercial extracts based on citric biomass named Ecolife ${ }^{\circledR}$ and Agromil ${ }^{\circledR}$ were tested at various dilutions on the mycelial growth inhibition of $P$. costarricensis. In vivo, coffee seedlings maintained in glasshouse, were sprayed with these extracts seven days before inoculation of $P$. costarricensis. Only extracts from citric biomass had inhibitory effects on the fungus. In vivo, Ecolife ${ }(5 \mathrm{ml} / \mathrm{l})$, Agromil ${ }(5 \mathrm{~g} / \mathrm{l})$ and the aqueous extract of rusted coffee leaves (dilution 1:6) reduced Phoma leaf spot. Both, Ecolife $₫$ and the extract of rusted coffee leaves were significantly more effective in reducing the area under the lesion progress curve when applied at lower doses, indicating a possible effect on the induction of resistance.
\end{abstract}

Additional keywords: Coffea arabica, fungal disease, control, induced resistance, elicitors.

\section{RESUMO}

Efeito de extratos provenientes de biomassa cítrica, folhas de café com ferrugem e cascas de frutos de café sobre Phoma costarricensis do cafeeiro

A mancha-de-Phoma, causada por Phoma costarricensis é uma séria ameaça a produção de café (Coffea arabica), especialmente nas terras altas do estado de Minas Gerais, Brasil. Extratos de biomassa cítrica, extratos de casca de café e de folhas de café severamente afetadas pela ferrugem (Hemileia vastatrix), foram avaliados contra P. costarricensis. Em um ensaio in vitro, o extrato aquoso de folhas com ferrugem e de casca de frutos, além dos extratos comerciais baseados em biomassa cítrica, chamados Ecolife ${ }^{\circledR}$ e Agromil ${ }^{\circledR}$, foram testados em várias diluições sobre o crescimento micelial de $P$. costarricensis. In vivo, mudas de café mantidas em casa de vegetação foram pulverizadas com esses produtos, sete dias antes da inoculação com $P$. costarricensis. Somente os extratos baseados em biomassa cítrica tiveram efeito inibitório sobre o fungo. In vivo, Ecolife ${ }^{\circledR}(5 \mathrm{ml} / \mathrm{l})$, Agromil ${ }^{\circledR}(5 \mathrm{~g} / \mathrm{l})$ e o extrato aquoso de folhas com ferrugem (diluição 1:6) reduziram a mancha-de-Phoma. Ambos, Ecolife ${ }^{\circledR}$ e o extrato de folhas de café com ferrugem foram significativamente mais eficazes em reduzir a área abaixo da curva de progresso da lesão, quando utilizados nas menores dosagens, o que é um indicativo de indução de resistência.

Palavras-chave adicionais: Coffea arabica, controle, resistência induzida, elicitores.

Phoma leaf spot caused by Phoma costarricensis Echandi may result in high losses at coffee (Coffea arabica L.) plantations in many countries, including Brazil (Echandi, 1957; Godoy et al., 1995). Under conditions of high relative humidity and moderate temperatures, the fungus infects mainly young leaves and shoots, leading to reduction of photosynthetic tissues. Almeida \& Matiello (1989) quantified losses ranging from 15 to $43 \%$ in the southern regions of Minas Gerais, Brazil.

The intense utilization of pesticides in coffee

\footnotetext{
${ }^{1}$ Part of the Master Dissertation of the first author. Universidade Federal de
} Lavras. (2004). plantations has lead to severe damage to the environment (Carvalho \& Chalfoun, 1998). Therefore, researchers have increased efforts in order to obtain alternative control measures to fight diseases on coffee.

There are many studies showing the efficacy of plant extract-based products controlling plant pathogens, although the majority of those have been done in vitro. In Brazil, there is growing interest in using residues of food the processing industry or the natural wastes from cash crops to reduce diseases either by their direct fungicidal effect or their resistance inducing effects. The following study was done to determine the effect of extracts of citric biomass, coffee berry 
husks and coffee leaves severely affected by rust (Hemileia vastatrix Berk \& Br.) on the mycelial growth of $P$. costarricensis and on coffee seedling protection from Phoma leaf spot.

Coffee berry husks (industrial residue) and rusted coffee leaves (collected from the soil surface of coffee plantations) were air dried and ground to powder in an electric mill. The powder of each was soaked in boiling water (proportion of 1:10 w/v) for $2 \mathrm{~h}$ while being stirred with a magnetic stirrer. The suspensions, here called Husk Aqueous Extract (HAE) and Leaf Aqueous Extract (LAE) were filtered and kept at $5{ }^{\circ} \mathrm{C}$. Ecolife $\AA$ and Agromil $\AA$, commercial products originated from citric biomass, were supplied by Quinabra S.A. (Química Natural Brasileira, São José dos Campos - SP, Brazil).

Inoculum was obtained from sporulating cultures of P. costarricensis which originated from coffee leaves, grown on potato dextrose agar (PDA). Colonies were kept in Petri dishes in the dark $\left(22 \pm 3{ }^{\circ} \mathrm{C}\right)$, for seven days. Mycelial disks $(0.5 \mathrm{~cm}$ diameter) cut from these cultures were used for in vitro and in vivo experiments.

Coffee seedlings, cv. Acaiá Cerrado were grown in plastic bags containing soil, bovine manure and sand (1:1:1 mixture), supplemented with macro and micronutrients to prevent mineral deficiencies. Seedlings, maintained in a glasshouse, were used to determine the effect of the extracts and commercial products on Phoma leaf spot.

For in vitro tests, aqueous extracts (HAE and LAE) at the dilutions of $1: 3$ and 1:6, were added to flasks containing PDA medium and autoclaved. Ecolife ${ }^{\circledR}(2.5$ and $5.0 \mathrm{ml} / \mathrm{l})$ and Agromil ${ }^{\circledR}(10 \mathrm{~g} / \mathrm{l})$ were sterilized under UV light for 30 min and added to the autoclaved medium. The PDA without amendment served as control. A mycelial disk of $P$. costarricensis was seeded at the center of each Petri dish. Plates were incubated in a growth chamber at $23{ }^{\circ} \mathrm{C}$ with 12 $\mathrm{h}$ photoperiod. There were eight replicates for each treatment, distributed in a randomized block design. Radial mycelial growth was measured six days after plating.

Seven days before inoculation with $P$. costarricensis, one-year-old coffee seedlings were sprayed with one of the following treatments: Agromil $\AA$ : $5 \mathrm{~g}$ of the commercial product/l of water; Ecolife $\AA$ : $5 \mathrm{ml}$ or $10 \mathrm{ml}$ of the commercial product/l of water; HAE: aqueous extract of coffee berry husk at dilution 1:3 or 1:6; LAE: aqueous extract of rusted leaves at dilution $1: 3$ or $1: 6$.

Seedlings sprayed with distilled water only served as control. A randomized block design was used, with four replicates of ten seedlings each/treatment. Seven days after spraying, one leaf with brilliant green color and soft texture was removed from the uppermost part of each seedling. Leaves were taken to the laboratory, washed with soap and rinsed with distilled water. The adaxial leaf surface was perforated with a needle and a mycelial disk of $P$. costarricensis was laid on the wound in each leaf. Leaves were incubated in plastic trays lined with wet towel paper, which were kept inside transparent plastic bags at room temperature $\left(22 \pm 3{ }^{\circ} \mathrm{C}\right)$.

Disease severity was assessed two, four and six days after inoculation. Lesions in all leaves were measured using the software UTHSCSA Image Tool for Windows, version 3.00, 2002. Data was converted to area under the lesion progress curve (AULPC), (Campbell \& Maden, 1990). Statistical analysis was performed using the statistical package SAEG.

The mycelial growth of $P$. costarricensis was not significantly affected by any tested dilution of coffee extracts. One of the possibilities for the absence of inhibitory effects of coffee extracts is due to the fact that extracts were autoclaved. Yin \& Tsao (1999) observed that inhibitory effects of aqueous extracts of Allium spp. diminished with the increase of temperature during their extraction, allowing the decomposition of antifungal compounds. Another possibility is that the time of extraction (only $2 \mathrm{~h}$ ), should be increased to try to optimize the extraction of possible antimicrobial substances.

On the other hand, the mycelial growth of $P$. costarricensis was significantly reduced by Ecolife $(\AA$ and Agromil ${ }^{\circledR}$ at all tested concentrations; the inhibition of growth increased with the increase of concentrations (Figure 1). Although these products have similar compositions, Ecolife ${ }^{\circledR}$ reduced mycelial growth more drastically than Agromil ${ }^{\circledR}$, probably due to the higher solubility of the former (manufacturer information). This trend was also previously observed in tests with Colletotrichum gloeosporioides Penz from coffee (Vilas Bôas et al., 2004).

The areas under the lesion progress curves (AULPC) of leaves sprayed with Ecolife ${ }^{\circledR}(5 \mathrm{ml} / \mathrm{l}), \operatorname{Agromil}{ }^{\circledR}(5 \mathrm{~g} / \mathrm{l})$ or with LAE (1:6) were significantly smaller than the areas of other treatments (Figure 2).

Both Ecolife ${ }^{\circledR}$ and LAE were more effective in reducing disease when applied at lower doses. If the extracts were strictly fungicides, a better disease control would be expected at higher concentrations. It is suggested that LAE, an extract from rusted coffee leaves, is a resistance inducer

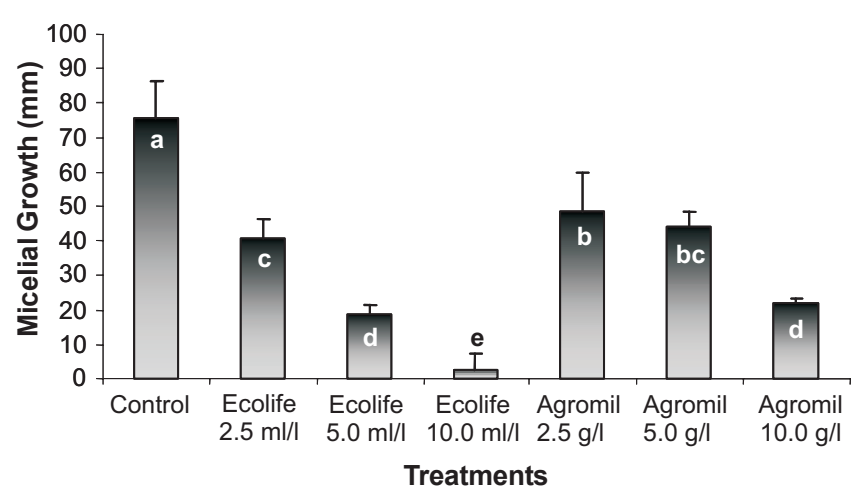

FIG. 1 - Effect of doses of Ecolife $(\AA)$ and Agromil $®$ on the mycelial growth of Phoma costarricensis. Treatments with the same letter do not differ by Duncan Test, at $5 \%$ of probability, $\mathrm{CV}=9.22 \%$. Bars represent standard deviations. 


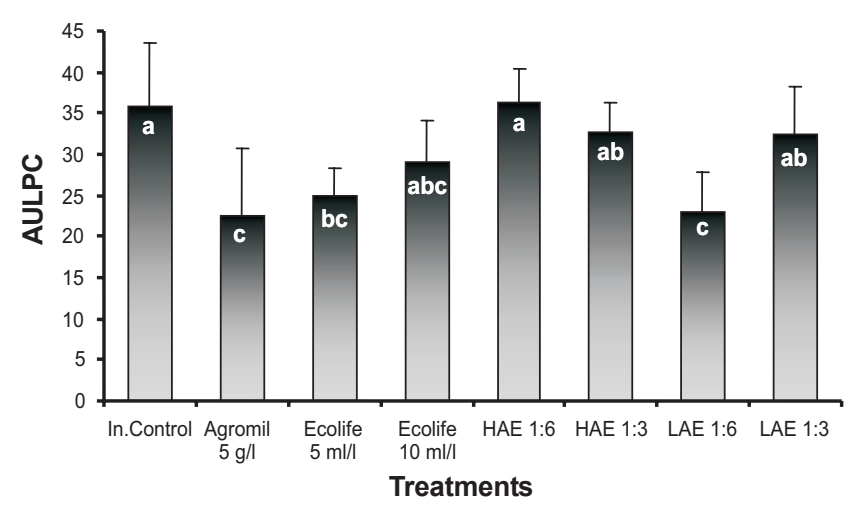

FIG. 2 - Areas under the lesion progress curves (AULPC) of treatments containing extracts from citric biomass (Ecolife $\AA$ and Agromil ${ }^{\circledR}$ ) or extracts from coffee (Coffea arabica) husks (HAE) or leaves (LAE), compared to the inoculated control. Treatments with the same letter do not differ by the Duncan Test at $5 \%$ probability, $\mathrm{CV}=18.88 \%$. Bars represent standard deviations.

since it presented no toxic effect in vitro and was more effective at a lower dose in vivo. In fact, substances extracted from uredospores of $H$. vastatrix induced defense responses against the same fungus, as measured by increased levels of phenolic compounds and activities of peroxidases and polyphenoloxidases (Maxemiuc-Naccache, 1983; Maxemiuc-Naccache \& Dietrich, 1985; Guzzo et al., 1987).

Bernardo et al. (2001), sprayed sorghum [Sorghum bicolor (L.) Moench.] mesocotyls with Agromil ${ }^{\circledR}$ before inoculation with a compatible Colletotrichum graminicola isolate and found a deposition of phenolic phytoalexins. The fact that Agromil ${ }^{\circledR}$ was not very toxic in vitro and showed a relative control of Phoma spot in vivo, suggests that it may act as an inducer of resistance, as well.

The raw materials to make HAE and LAE are very abundant in Brazil. Coffee husks, for instance, are residues of the coffee industry and have in their soluble fraction, mainly carbohydrates (including 12\% pectin), proteins and tannins (Pandey et al., 2000). Rusted coffee leaves are fully available in fields and generally fall onto the soil surface, even during harvest; we suppose they posses elicitors, both, of fungal and plant origin, which are being currently investigated.

\section{LITERATURE CITED}

ALMEIDA, S.R. \& MATIELLO, J.B. Estudo de novos produtos para controle químico à Phoma spp. em cafeeiros, em nível de campo. Anais, $15^{\circ}$ Congresso Brasileiro de Pesquisas Cafeeiras, Maringá. 1989. pp.145-146.

BERNARDO, R., SCHWAN-ESTRADA, K.R.F., STANGARLIN, J.R. \& FIORI, A.C.G. Efeito de extratos cítricos na indução de resistência e no crescimento micelial de fungos fitopatogênicos. Fitopatologia Brasileira 26: 313. 2001. (Resumo)

CAMPBELL, C.L. \& MADDEN, L.V. Introduction to Plant Disease Epidemiology. New York: John Wiley \& Sons Inc.1990.

CARVALHO, V.L. \& CHALFOUN, S.M. Manejo integrado das principais doenças do cafeeiro. Informe Agropecuário 19:2735.1998 .

ECHANDI, E. La quema de los cafetos causada por Phoma costarricensis. Revista de Biología Tropical 5:81-102. 1957.

GODOY, C.V., BERGAMIN FILHO, A. \& SALGADO, C.L. Doenças do cafeeiro (Coffea arabica L.) In: Kimati, H., Amorim, L., Bergamin Filho, A., Camargo, L.E.A., \& Rezende, J. A.M. (Eds.). Manual de Fitopatologia, 1997, v. II, pp.184-200.

GUZZO, S.D., MARTINS, E.M.F. \& MORAES, W.B.C. Induced protection of coffee plants to Hemileia vastatrix. I. Partial purification of the extracellular inducer from heat-killed urediniospores of the pathogen. Fitopatologia Brasileira 12:377385. 1987.

MAXEMIUC-NACCACHE, V. Alterações bioquímicas em folhas de Coffea arabica resistentes e suscetíveis à infecção por Hemileia vastatrix (ferrugem do cafeeiro). (Tese de Doutorado). São Paulo. Escola Paulista de Medicina. 1983.

MAXEMIUC-NACCACHE, V. \& DIETRICH, S.M.C. Changes in phenols and oxidative enzymes in resistant and susceptible Coffea arabica inoculated with Hemileia vastatrix (coffee rust). Revista Brasileira de Botânica 8:185-190. 1985.

PANDEY, A., SOCCOL, C.R., NIGAM, P., BRAND, D. MOHAN, R. \& ROUSSOS, S. Biotechnological potential of coffee pulp and coffee husk for bioprocesses. Biochemical Engineering Journal 6:153-162. 2000.

VILAS BÔAS, C.H., BARRETO, S.S., BARGUIL, B.M. \& RESENDE, M.L.V. Efeito do Ecolife $(\AA)$ no crescimento micelial de Colletotrichum sp. Fitopatologia Brasileira 30:158. 2004. (Resumo)

YIN, Mei-chin \& TSAO, Shih-ming. Inhibitory effect of seven Allium plants upon three Aspergillus species. Internacional Journal of Food Microbiology 49:49-56. 1999. 